\begin{tabular}{ll}
\hline 原 & 著 \\
\hline
\end{tabular}

\title{
澱粉性食品の食衛生学的研究（第 1 報） Starchy Foods in View of Hygiene (Report 1)
}

\author{
小麦粉団子の沛で操作と保存性との関倸 \\ Studies on Relationship between Boiling and Preservation of Dough
}

愛 知 県 衛生 研 究 所

(Aichi Institute of Public Health)

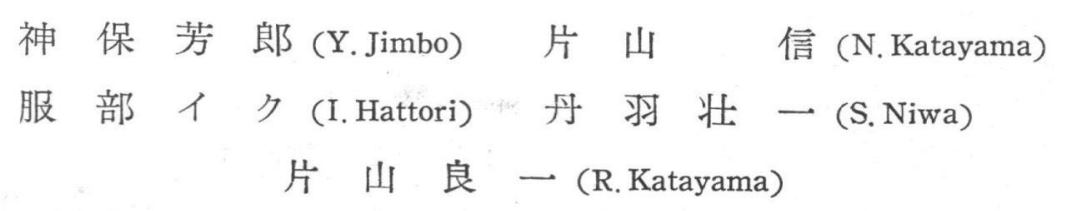

We performed experiments using dough in order to examine influence of boiling, preservation and vitamin $\mathrm{B}_{1}$-enrichment on the bacterial counts of the noodle.

The dough contained about $10^{4} \sim 10^{5}$ of bacterias in one gram before the experiments. After boiling the most part of bacterias were sterilized, while few thermo-resistant bacterias remained and their counts were very uneven.

Experiments using dough enriched with various amounts of vitamin $B_{1}$ revealed that vitamin $\mathrm{B}_{1}$ had no influence on bacterial growth during preservation.

わが国における澱粉性加工食品としての麵類は，古来からその代表のひとつとなっている。 最近ではそれらの麵類は調理に容易なゆで麵にまで量産加工され，さらにビタミン $\mathrm{B}_{1}$ などの栄養強化もお こなわれて包装製品として市販されるようになってきた。

ゆで麵は沸騰水中でゆであげてあるので, 一般的衛生的なものと考光られている。しかしながらこ机らは 水分が $70 \%$ 以上にもおよぶ細菌の増殖に好適な澱粉性主食品であり, またそれらの製品に一定の保存性をあた えるばあいに宮禾のすでに論ずるごとく, その原料, 加工法などの制約を受けて, しばしば非衛生的なるのと なるおそれがある。

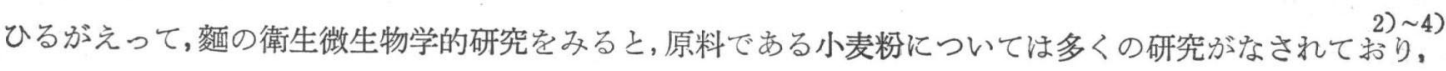
原料の微生物学的污染度が, その製品の保存性に重大な影響をあたえるであろうことは相像にかたくないが, それらの製品, なかえずくゆで麵の污染状況については柳沢の報告があるのみで, その保存性についての研究 はみあたらない。 
そこで著者らは食衛生学的立場から, 麵類のゆで操作と保存性の問題を解決する目的で, まず実験条件を一 定とするために，麵用小麦粉を用いて麵と同じ方法で製造した団子について，そのゆで操作および保存による 細菌数の消長およびそのビタミン $\mathrm{B}_{1}$ 強化の影響についての実験をおこなった結果, ゆで操作後における残存 細菌数の不均一なとと,およびビタミン $\mathrm{B}_{1}$ 強化が細菌増殖に影響をおよぼさないことがわかったので,ここ にその成績の概要を報告する。

\section{実験材料および方法}

（I） 実験材料：小麦粉は日清製粉中力粉（ビタミン $\mathrm{B}_{1}$ 含量 $0.176 \mathrm{mg} \%$ )で，食塩は市販のものとした。 用水は名古屋市上水道定使用した。強化用のビタミン $\mathrm{B}_{1}$ は武田薬工製食品添加物のジベンゾイルチアミンを 使用した。

（II）実験方法: 小麦粉 $100 \mathrm{~g}$ を $6 \%$ の食塩水 $50 \mathrm{ml}$ でこねあわせ, さらに練りのばして生地をつくり, $2 \mathrm{~g}$ 宛を 1 個として径 $31 \mathrm{~mm}$, 厚さ1. $3 \mathrm{~mm}$ の扁平な団子に成形した。この団子各 10 個を径 $90 \mathrm{~mm}$, 深さ $20 \mathrm{~mm}$ の滅 菌シャーレーに採取した。つぎに団子各 1 個ずつについて，ゆで時間10，15，20および25分の時間別により， 容器は $500 \mathrm{ml}$ 容滅菌ビーカーの沸騰水中でゆであげ, ゆで団子とし, 〔水洗（さます）操作は再污染をさけるた め除外した。】各 1 個あてを前記同様の滅菌シャーレーに採取した。つぎに団子 3 個あてを 3 個の $500 \mathrm{~m} 1$ 容の 滅菌ビーカー別に沸騰水中で 15 分間ゆであげ， $300 \mathrm{ml}$ の用水で水洗の上，それ定 6 および 24 時間保存した後， 各1個あてを滅菌シャーレーに採取した。

ついで各団子生地に，ジベンゾイルチアミン(ビタミン $\mathrm{B}_{1}$ として強化量：ゆで団子でき上り $3.2 \mathrm{~g} に$ 対し， それぞれ $0,1 ， 10$ 少よび $100 \mathrm{mg} \%$ の 4 種類となるように） $0 ， 0.046 ， 0.465 ， 4.650 \mathrm{mg}$ の 4 種類の強化量別に 著者らの麵の中心部にビタミンを添加する方法で強化をおこない，前述と同様の団子とし，15分間ゆであげ， $300 \mathrm{ml}$ の用水で水洗をおこないビタミン $\mathrm{B}_{1}$ 強化ゆで団子とした後, 各 1 個女てを滅菌シャーレーに採取した。

以上, 調製した試料を, 細菌培楸恒温槽 $\left(37^{\circ} \mathrm{C}\right)$ に 24 時間保存し, 増殖した細菌を混䣋平板培養法 $\left(37^{\circ} \mathrm{C}\right.$, 48時間) により測定し, 被検材料 $1 \mathrm{~g}$ に換算して表示して,これをゆで団子の腐敗の指標とした。なおビタミ ン $\mathrm{B}_{1}$ はアルカリ分解の上, チオクローム熄光法を適用, 螢光光度計で測定した。

\section{実験成績および考察}

(I） 団子生地のばあい

小麦粉を用いて麵と同様の方法で調製した団子生地 10 検体について $37^{\circ} \mathrm{C}, 24$ 時間保存後における細菌数を しらべた。その成績は表 1 に示すごとくであった。すなわち，1 $\mathrm{g}$ 中 $10^{4} 〜 10^{5}$ の細菌数をみとめた。

(II) ゆで団子のばあい

(a) ゆで時間別による細菌数

ゆで団子の保存後における，ゆで時間別の細菌数をしらべた成績は表 2 に示すごとくである。すなわち，ゆ で時間10分から25分では団子に含有している細菌は大部分死滅するが, 耐熱性細菌が残存することは, 当然と 考えられる。また本実験 4 回の反復において,ゆで時間とは関倸なく一部の細菌の増殖がみとめられたこと は, 団子に含有している細菌が著しく不均一な分布を示すものと解される。

\section{(b) 保存時間別による細菌の消長}

ゆであげ直後, 6 および 24 時間 $37^{\circ} \mathrm{C}$ 保存後の細菌数をしらべたところ, 表 3 に示すごとくであった。すな

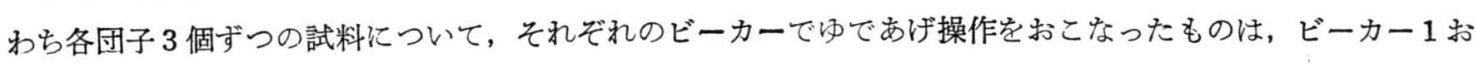


よび 3 の実験においては，ゆで直後から保存24時間に至るまで細菌の発育はみとめられなかった。

ビーカー 2 の実験においては ゆで直後および保存 6 時間にお いて細菌の発育はみとめられな かったにもかかわらず，保存 24 時間後において $10^{2} \sim 10^{4}$ の細菌 がみとめられた。このことはゆ で直後きわめて少量の細菌が残
表 1 団子生地の保存後における細菌数（試料 $1 \mathrm{~g}$ 中）

\begin{tabular}{|c|c||c|c|}
\hline 試料番号 & 細 菌 数 & 試料番号 & 細 菌 数 \\
\hline 1 & $1.2 \times 10^{5}$ & 6 & $1.7 \times 10^{6}$ \\
2 & $1.9 \times 10^{4}$ & 7 & $1.8 \times 10^{5}$ \\
3 & $2.7 \times 10^{4}$ & 8 & $1.6 \times 10^{5}$ \\
4 & $7.8 \times 10^{4}$ & 9 & $9.1 \times 10^{4}$ \\
5 & $5.6 \times 10^{5}$ & 10 & $1.8 \times 10^{5}$ \\
\hline
\end{tabular}

存しているにもかかわらず, 細菌数測定の一般的試験法では測定不能の量であり, これを24時間保存したばあ 表 2 ゆで時間別によるゆで団子の保存後における細菌数（試料1 $\mathrm{g}$ 中）

\begin{tabular}{|c|c|c|c|c|}
\hline \multirow{2}{*}{ 反復 } & \multicolumn{2}{|r|}{ で } & 間 & 分) \\
\hline & 10 & 15 & 20 & 25 \\
\hline 1 & $(-)$ & $(-)$ & $5.2 \times 10^{5}$ & $9.1 \times 10^{5}$ \\
\hline 2 & $(-)$ & $7.8 \times 10^{5}$ & $(-)$ & $(-)$ \\
\hline 3 & $(-)$ & $(-)$ & $(-)$ & $(-)$ \\
\hline 4 & $(-)$ & $(-)$ & $(-)$ & $(-)$ \\
\hline
\end{tabular}

いは, 細菌が増殖し, 同様の試験法 で十分測定される細菌数に達した ものと思わ机る。上のことから 団子に含有している細菌は, 沸騰 水中で,その大部分が死滅するが, なお少量の耐熱性細菌の残存はま ぬかれないことがわかった。

（III）ゆで団子に強化されたビタミン $\mathrm{B}_{1}$ と細菌の増殖との関係

麵にビタミン $\mathrm{B}_{1}$ を強化するばあい, 巷間では非強化悳にくらべて強化麵が腐敗し易いといわ秃ているので, 強化ビタミン $\mathrm{B}_{1}$ がはたして細菌の増殖に影響をおよぼすかどうかを検討する目的で，現在最も多くその強 化に使用されている水に難溶のジベンゾイルチアミンを使用して, 添加量別に強化団子生地をつくり, それを 沸騰水中で15分間㠴でげ, $300 \mathrm{ml}$ の用水で水洗をおこなったものを保存した後, それぞれの細菌数究測定し た。その結果は表 4 に示すごとくであり，4回の反復実験において,ビタミン $\mathrm{B}_{1}$ の量とはなえらの関係なら， 細菌の発育呈全くみとめかったものと、1 $10^{3} \sim 10^{5}$ 程度の細菌を検出したものとがみとめられた。

強化ゆで団子のビタミン $\mathrm{B}_{1}$ 含量および水分量は表 5 に示したとおりである。なお，団子生地およびゅで操 作に使用した用水の細菌数をしらべたところ，いずれも陰性であった。

以上の実験結果から, 団子生地をとのまま保存 した場合は， $1 \mathrm{~g}$ 中 $10^{4} \sim 10^{5}$ 程度の細菌が含有さ れていたが，これを沸騰水中でゆで操作をおこな ったばあいは, 大部分の細菌を死滅させられるが, な扮少量の耐熱性細菌が残存し，乙かも，それら の分布は著しく不均一であることが判明した。こ れら団子による実験の結果から，麵類などの澱粉 性食品においても同様のことが考えられる。この ことからゆで麵に京いても,ただ単にゆで操作や, 包装のみによって一定の保存性をあたえることは 必ずしも容易ではないことが推察される。またゆ で喕にビタミン $\mathrm{B}_{1}$ 強化したばあいでも, 無添加 表 3 保存時間別による币で団子の細菌数 (試料 $1 \mathrm{~g}$ 中)

\begin{tabular}{|c|c|c|c|c|}
\hline \multirow{2}{*}{$\begin{array}{l}\text { で } \\
\text { ビーカ } \\
\text { 一別 }\end{array}$} & \multirow{2}{*}{$\begin{array}{l}\text { 試 料 } \\
\text { 番 号 }\end{array}$} & 保 存 & 時 & (時間) \\
\hline & & 直 後 & 6 & 24 \\
\hline \multirow{3}{*}{1} & 1 & $(-)$ & $(-)$ & $(-)$ \\
\hline & 2 & $(-)$ & $(-)$ & $(-)$ \\
\hline & 3 & $(-)$ & $(-)$ & $(-)$ \\
\hline \multirow{3}{*}{2} & 1 & $(-)$ & $(-)$ & $2.9 \times 10^{2}$ \\
\hline & 2 & $(-)$ & $(-)$ & $1.3 \times 10^{2}$ \\
\hline & 3 & $(-)$ & $(-)$ & 3. $7 \times 10^{4}$ \\
\hline \multirow{3}{*}{3} & 1 & $(-)$ & $(-)$ & $(-)$ \\
\hline & 2 & $(-)$ & $(-)$ & $(-)$ \\
\hline & 3 & $(-)$ & $(-)$ & $(-)$ \\
\hline
\end{tabular}


のものにくらべて強化ビタミン $\mathrm{B}_{1}$ の細菌 の増殖におよぼす影響はみとめられないも のとみなされる。

\section{結 論}

麵のゆで操作およびビタミン $\mathrm{B}_{1}$ 強化と 保存性との関係について小麦粉団子による 実験をおこなった。
表 4 強化师で団子の保存後における細菌数（試料 $1 \mathrm{~g}$ 中） ビタミン $\mathbf{B}_{1}$ 強化量 $(\mathrm{mg} \%)$

\begin{tabular}{|c|c|c|c|c|}
\multirow{2}{*}{ 反復 } & \multicolumn{3}{|c|}{ ビ タミン $\mathbf{B}_{1}$ 強 化量 $(\mathrm{mg} \%)$} \\
\cline { 2 - 5 } & 0 & 1 & 10 & 100 \\
\hline 1 & $2.1 \times 10$ & $1.7 \times 10^{5}$ & $(-)$ & $($ - $)$ \\
2 & $2.6 \times 10^{5}$ & $1.9 \times 10^{5}$ & $1.4 \times 10^{3}$ & $($ - $)$ \\
3 & $5.2 \times 10^{5}$ & $3.6 \times 10^{3}$ & $(-)$ & $3.1 \times 10^{5}$ \\
4 & $(-)$ & $(-)$ & $(-)$ & $(-)$ \\
\hline
\end{tabular}

表 5 強化师で団子のビタミン $\mathrm{B}_{1}$ 含量

\begin{tabular}{|c|c|c|c|c|c|}
\hline \multirow{2}{*}{ 反 復 } & \multirow{2}{*}{ 成分 } & \multicolumn{4}{|c|}{ ビタミン $\mathbf{B}_{1}$ 強 化 量 $(\mathrm{mg} \%)$} \\
\hline & & 0 & 1 & 10 & 100 \\
\hline \multirow{2}{*}{1} & ビタミン $\mathrm{B}_{1} \quad \mathrm{mg} \%$ & 0.064 & 0.957 & 9. 195 & 91.137 \\
\hline & 水分含 量 \% & 66.4 & 66.4 & 66.2 & 66.4 \\
\hline \multirow{2}{*}{2} & ビタミン $\mathrm{B}_{1} \quad \mathrm{mg} \%$ & 0.056 & 0.918 & 9. 381 & 94.825 \\
\hline & 水 分含 量 \% & 66.5 & 66.8 & 67.0 & 67.0 \\
\hline \multirow{2}{*}{3} & ビタミン $\mathrm{B}_{1} \quad \mathrm{mg} \%$ & 0.058 & 0.907 & 9. 555 & 93.651 \\
\hline & 水 分 含 量 \% & 67.3 & 67.2 & 67.1 & 67.3 \\
\hline \multirow{2}{*}{4} & ビタミン $\mathrm{B}_{1} \quad \mathrm{mg} \%$ & 0.060 & 0.920 & 9. 772 & 92.763 \\
\hline & 水分 含 量 \% & 66.5 & 67.2 & 66.8 & 67.0 \\
\hline
\end{tabular}

団子生地をそのまま保存した場合は，1 $\mathrm{g}$ 中 $10^{4} \sim 10^{5}$ 程度の細菌が含有されていたが，これを沸騰水中で， ゆで操作をおこなったばあいは大部分の細菌は死滅し，なお少量の耐熱性細菌は残存した。しかもこれら残存 細菌の分布は極めて不均一であった。

ビタミン $\mathrm{B}_{1}$ 強化ゆで団子の保存後における細菌数をしらべたところ，その細菌増殖におよぼすビタミン $\mathrm{B}_{1}$ 強化の影響はみとめられなかった。

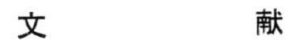

1) 宮木高明：科学, 35, 345 (1965)

2) F. W. TANNER : "Microbiology of Food" 2nd Ed., (1946) Garrard Press

3）太田輝夫, 中野政弘：日本食品工業学会誌，10，507 (1963)

4）木俣正夫，曾々木淑子：日本水産学会誌，22，269（1956）

5）柳沢文徳：腐敗研究所報告, 9, 59 (1956)

6）丹羽壮一, 片山信, 服部イク, 神保芳郎, 片山良一：ビタミン，32，401 (1965)

7）厚生省編：食品衛生検查指針（Ｉ）（1960）（協同医書出版社）

8）柳沢文德：食品工業，2，6，43 (1959)

9）鎌田政喜, 堀正剛：武田年報，14，19（1955）

10）八木国夫編：最新ビタミン定量法，12（1954）（医歯薬出版） 